\title{
The effect of family formation on the build-up of pension rights among minority ethnic groups and native women in Belgium
}

\author{
KAREL NEELS*, DAVID DE WACHTER* and HANS PEETERS $†$
}

\begin{abstract}
Gender penalties in pension outcomes are widely acknowledged and have been documented for majority populations in various settings. A recurring finding is that the gendered impact of family formation on work-care trajectories adversely affects women's accumulation of pension rights over the lifecourse relative to men. Although maternal employment is particularly low in migrant populations, few papers have explicitly addressed pension protection of migrant women. Using longitudinal microdata from the Belgian Social Security Registers, we analyse whether entry into parenthood differentially affected the build-up of first pillar pension rights of working-age migrant women compared to natives between 1998 and 2010, further distinguishing by origin group and migrant generation. The results show that native women are most likely to build up pension rights through full-time employment both before and after parenthood. In contrast, first-generation women and women of Turkish and Moroccan origin are more likely to build up pension rights though assimilated periods or rely on derived pension rights after parenthood, even when controlling for type of pension build-up before parenthood. We conclude that policies reinforcing individualisation of pension rights based on employment or decreasing the importance of derived rights may erode pension protection of groups having limited access to the labour market, and require co-ordination with employment and family policies that support the combination of work and care responsibilities.
\end{abstract}

KEY WORDS - family formation, pension rights, migrant women, migrant generation, longitudinal data, Social Security Registers, Belgium.

* Centre for Longitudinal \& Life Course Studies, University of Antwerp, Belgium.

$\dagger$ Federal Planning Bureau (this article was written during a previous employment at the Centre for Sociological Research, KU Leuven). 


\section{Introduction}

A well-corroborated finding from research on pension outcomes is that the average retirement pension of women lies substantially below that of men (Bettio, Tinios and Betti 2013). Women's pension rights suffer as a result of family formation and the gendered division of paid work and care responsibilities that emerges following parenthood (Renga, Molnar-Hidassy and Tisheva 2010). Parenthood leaves a larger footprint on women's professional careers, in the short run because women temporarily or permanently withdraw from the labour market or cut back on working hours shortly before and after giving birth, and in the long run because of missed promotion opportunities (Becker 1991; Liefbroer and Corijn 1999). As women continue to take up the majority of the child-care responsibilities, the aggregate results are lower wages and reductions in lifetime earnings (Davies, Joshi and Peronaci 2000; Sigle-Rushton and Waldfogel 2007), which typically translate into pension penalties in interaction with most pension systems.

Although research on inequalities in pension protection has to a large extent focused on gender differentials, an increasing number of studies suggest that ethnic differentials are an important source of social inequality (Samek Lodovici et al. 2011 ). Migrant populations have increased substantially in many European countries over the last decades, but the labour market prospects of migrants (and their children) are less favourable than for majority populations in labour markets across Europe (Organisation for Economic Co-operation and Development (OECD) $2010,2011 b)$. Not only are people of migrant origin less likely to be employed, they generally receive lower wages, more frequently have shortterm contracts, and are over-represented in blue-collar jobs or secondary positions in the labour market (Corluy and Verbist 2014; OECD 2008; Urso and Schuster 2013). Facing a double disadvantage as a result of combining disadvantages related to both gender and ethnicity (Rubin et al. 2008), migrant women experience more difficulties than native women in securing a position in the labour market, and ethnic penalties have been shown to be larger for women than is the case for men (Corluy and Verbist 2014; Urso and Schuster 2013). Considering the links between family formation, employment trajectories and pension protection, migrant women are much less likely than natives to combine employment with having young children (Rubin et al. 2008). Although research specifically focusing on pension protection of migrant women is limited, available research suggests that gender penalties in pension outcomes are more articulated in minority populations, with migrant women being less likely 
to have access to basic pension programmes, occupational pensions and private pensions, and showing larger reliance on means-tested benefits in old age as a result (Ginn and Arber 2001).

Using longitudinal micro-data from the Belgian Social Security Registers from 1998 to 2010 , this paper studies whether entry into parenthood and subsequent family formation differentially affects the build-up of pension rights of first, second and later generations of migrant women of different origin groups compared to natives. The interaction between family formation, work-care trajectories and pension outcomes is gaining relevance as policy reforms propagating individual pension rights based on labour market participation, privatisation of pension systems and decreased importance of derived pension rights are likely to erode pension protection of groups having limited access to the labour market, such as migrant women (Frericks, Maier and De Graaf 2007; Price 2007; Vlachantoni 2010). Belgium is a particularly relevant case to illustrate how the interaction between labour market outcomes and pension systems generates ethnic penalties in women's pension protection as the country has the largest employment rate gap between migrants and natives of all OECD countries (Corluy and Verbist 2014; OECD 2008), while pension protection is highly dependent on past work behaviour, with only limited recognition of care periods (Leitner 2001). We focus on women of working age to anticipate future developments in women's pension protection rather than considering pension outcomes of currently retired women which reflect the experience of older cohorts who on average had higher completed fertility (Wood, Neels and Kil 2014) and who were less likely to be employed both before and after entry into parenthood compared to younger cohorts (OECD $2011 a$ ).

The subsequent sections provide the necessary background for our empirical study by considering the mechanisms that give rise to gender penalties in pension protection and how these have been shown to affect pension protection of migrant women. Subsequently, we specifically address the labour market position of migrant women in Belgium and some specificities of the Belgian pension system.

\section{Gender penalties in pension protection}

Gender penalties in pension outcomes are widely acknowledged and have been documented for a variety of settings (Bonnet, Buffeteau and Godefroy 2006; Bonnet, Meurs and Rapoport 2015; Even and Macpherson 1994; Ginn and Arber 1993; Grady 2015; Leitner 2001; Lewis 2001; Marier 2007; Meyer and Bridgen 2008; O'Rand and Shuey 
2007; Peeters 2016; Vlachantoni 2010). A recurring finding is that the gendered division of domestic responsibilities, and its effect on women's labour market trajectories (e.g. career length, hours worked, sector of employment and wage levels), adversely affects the accumulation of pension rights over the lifecourse relative to men.

The interaction of these gendered work-care trajectories with pension systems determines the size of penalties incurred by women, which are subject to substantial variation between countries (Leitner 2001). Gender discrimination in pension outcomes is found to be lower in countries having established universal pension schemes which provide individualised pension benefits regardless of past work behaviour and care arrangements. Most countries, however, have implemented employment-related pension schemes, which means that, depending on the characteristics of the pension scheme, differential work behaviour is translated into old-age security systems to a variable degree. First of all, gender penalties may result from specific qualifying conditions to gain access to the pension scheme (e.g. minima in terms of working hours, duration of work contract, wages or qualifying period) as these conditions tend to penalise discontinuous careers and lower wages, typical characteristics of women's work trajectories (Leitner 2001; Rubin et al. 2008). For those having access to the pension scheme, the maximum number of coverage years and the earnings actually considered in benefit calculations (e.g. earnings in a limited reference period versus average lifetime earnings), as well as limitations on credits granted for care work, may further privilege continuous employment careers to a variable degree (Leitner 2001 ).

\section{Gender, ethnicity and pension outcomes}

Whereas gendered work-care trajectories have been shown to entail gender penalties in majority populations across Europe, migrant women typically face a double disadvantage in the labour market, combining disadvantages related to both gender and ethnicity (Rubin et al. 2008). Allowing betweencountry variation, migrant women are characterised by lower labour force participation rates, higher unemployment levels and more precarious employment positions in labour markets across Europe. Migrant women are also less likely than natives to combine employment with having young children (Rubin et al. 2008). Although only a limited number of studies have addressed the interaction between pension systems and the differential work-family trajectories of migrants compared to natives (Ginn and Arber 2001; Hersch and Whitemeans 1993; Marier and Skinner 2008; Vlachantoni et al. 2015 ), results show that pension rights are typically 
lower among migrant women as a result of lower labour force participation, shorter employment careers, higher unemployment levels, under-employment (involuntary part-time work), and occupational segregation in employment sectors and jobs providing lower wages and limited access to pension benefits. In addition, formal criteria explicitly related to length of residence in the country may specifically affect migrant groups.

Using the 1988 Current Population Survey of employer benefits for the United States of America (USA), Hersch and Whitemeans (1993) show that women, and predominantly black women, face a large compensation disadvantage relative to white men. With respect to pension benefits, the proportion of black women being covered by pension benefits was found to be lower than among black and particularly white men, but not substantially different from white women. Using three waves of the British family resources survey (1994/5, 1995/6 and 1996/7), Ginn and Arber (2001) document ethnic disadvantage in protection from private pension schemes as a result of lower full-time employment, employee status, occupational class and earnings. As a result, minority ethnic groups, particularly women, are expected to disproportionately depend on means-tested benefits in later life, due to the combined effects of lower private pension coverage and the policy of shifting pension provision to the private sector. Focusing on pension protection in Canada and using data from the survey of Labour and Income Dynamics from 1994 and 2004, Marier and Skinner (2008) show that the earnings-related pension system accentuates disparities in the labour market, causing women and immigrants to have lower earnings in retirement. Elderly single women and post-1970 immigrants are more likely to rely on the means-tested component of the Canadian pension system, reflecting low public and private pension contributions as a result of interrupted career patterns in the case of women, and residency requirements attached to basic pension programmes as well as shorter careers in the case of immigrants. Finally, using data from the United Kingdom Household Longitudinal Survey from 2009 to 2011, Vlachantoni et al. (2015) show that membership in employer pension schemes complementing the relatively low-value Basic State Pension is lower among working-age individuals from minority ethnic groups than among the white British group, concluding that ethnicity remains a strong determinant of pension protection prospects through being in paid work, being an employee and working for an employer who offers a pension scheme. Compared to white British women, migrant women show significantly lower probabilities of being in paid employment, as well as a lower probability of working for an employer offering a pension scheme. 


\section{Migrant populations in Belgium}

Starting from the early $195^{\mathrm{os}}$, Belgium recruited labour migrants who predominantly originated from Italy. Following the mining accident in Marcinelle in $195^{6}$, Italian migration halted, however, leading to the inflow of labour migrants from other Southern European countries and later labour migration from Turkey, Morocco, Tunisia and Algeria (Vause 2013). As in other European countries, the 'migration stop' in 1974 closed the pathway of immigration to Belgium for non-European Union (EU) citizens on the grounds of work-related reasons, with labour migration for non-EU citizens only being granted for schooled migrants since (Eggerickx, Kesteloot and Poulain 1999). For non-EU citizens, the only other possibilities to gain residence in Belgium were to apply for asylum or refugee status, or through family reunification. Although the latter measure was initially intended to allow labour migrants to bring over their spouses and family members, their children often married partners from the parents' country of birth. Marriage migration is largely confined to the Turkish and Moroccan populations, with recent figures for Flanders (the northern Dutch-speaking part of Belgium) indicating that about half of the Turkish and Moroccan second-generation men and women married a partner from Turkey or Morocco up to 20o8, resulting in a continued inflow of first-generation migrants in these origin groups (Corijn and Lodewijckx 2009).

As in other EU countries, a new stream of migrants entered Belgium starting from the late 1990 , adding to the heterogeneity of the migrant population. This stream consisted largely of asylum seekers and refugees coming from outside the EU. Following the enlargement of the EU in the early 2ooos, Belgium also witnessed an increasing influx of labour migrants coming from East and Central Europe, and more recently, Southern Europe (Federaal Planbureau 2013). Besides the aforementioned migration streams, there has been a steady influx over the past decades of West European migrants, mostly coming from Belgium's neighbouring countries such as the Netherlands, France and Germany (Federaal Planbureau 2013; Lodewijckx 2013).

Although the number of people with a migrant background has steadily increased, the labour market position of migrants is lagging compared to natives (Münz et al. 2007). The labour market position of migrant women is subject to considerable variation, however, in terms of origin group and migrant generation. Employment rates of women originating from Western and Southern Europe are generally lower than those of native women, but the differences between these origin groups are not very 
articulated (OECD 2011b). Employment rates are considerably lower, however, in the Turkish and Moroccan populations (OECD 2008). Employment rates also vary significantly within origin group, with rates being typically higher for second-generation migrant women than for first-generation migrant women (Heath, Rothon and Kilpi 2008; Timmerman, Vanderwaeren and Crul 2003). The employment rate of second-generation migrant women is still lower than that of the majority population, however, particularly for second-generation Turkish and Moroccan women (Holland and De Valk 2013; OECD $2011 b$ ).

Whereas the effect of family formation on women's employment has been well documented for the majority population, the effect of parenthood on maternal employment in migrant groups has received more limited attention in the literature and the available evidence has been mostly based on cross-sectional data (Kil et al. 2015). A recent study based on longitudinal microdata from the Belgian Social Security Register shows that the parenthood penalty on maternal employment is more articulated among migrant women than is the case among natives. Although migrant women are only slightly more likely than women of Belgian origin to retreat from the labour market altogether, they do suffer a significantly higher risk of becoming unemployed following family formation. As a result, maternal employment rates strongly differ between origin groups, and women of Turkish and Maghreb origin are less likely to be employed following family formation than women of European origin (Kil et al. 2015).

\section{Work behaviour discrimination in the Belgian pension system ${ }^{1}$}

The Belgian pension system consists of three pillars. The first pillar consists of the legal pension entitlements that persons automatically build up through their own labour force participation (retirement pension) or through the labour force participation of a former spouse (derived pension rights). The modalities of the retirement pension depend on whether pension rights are built up in the employee scheme, the selfemployed scheme or the civil servant scheme (e.g. with respect to benefit calculation and the level of the guaranteed minimum pension), on average resulting in higher pensions for civil servants than for employees, who in turn have higher pensions on average than the self-employed. However, a common characteristic to all schemes is that pension rights are granted to people formerly employed in the formal labour market and that one is entitled to a retirement pension after reaching the official retirement age of 65 years. In all schemes, the level of the retirement pension depends on the former earnings and the length of the career. As a result, the 
Belgian pension system has been considered as highly discriminatory in terms of previous work behaviour from a comparative perspective (Leitner 2001; Marier 2007). Pension rights can also be granted for nonactive periods (albeit to a lesser extent in the self-employed scheme). During these so-called 'assimilated periods', individuals can build up pension rights when they are unemployed (unrestricted in time until 2011 ) or when they take up maternity or care/parental leave (maximum of two years). The prerequisite to receive assimilated pension rights, however, is that one has been formally employed before and that one is not voluntarily inactive (except when on maternity or parental leave). The pension credits that one builds up during assimilated periods are based on previous earnings (Peeters 2016). Individuals who receive no or just a small retirement pension can be entitled to derived pension rights (e.g. survivor's pension for widowers and/or divorce pension for divorced individuals), provided one is married or has been married in the past. Unmarried co-habitants (whether factual or legal co-habitants) are not eligible to receive derived pension rights. The level of the derived pensions is typically related to the retirement pension of the former spouse, resulting in variation in benefit levels between pension schemes (Peeters 2016).

Apart from the first pension pillar, the second pillar consists of supplementary pension rights that are granted to employees by companies and employment sectors, or that are built up voluntarily by self-employed workers. Similarly, the third pillar consists of supplementary pension entitlements which people fund by themselves by taking part in pension saving programmes or by taking out life insurance, regardless of their labour market activity (Peeters 2016). Finally, in addition to the three pillars, a means-tested minimum income provision exists as a last resort for those not sufficiently protected by earnings-related and/or family worker benefits (Peeters 2016). In this paper, however, we restrict our attention to differential pension protection under the first pillar.

\section{Research hypotheses}

Although migrant women in Belgium are subject to the same pension regulations as women from the majority population, differential work-family trajectories around parenthood among migrant women compared to natives are expected to translate into differential pension penalties given the work-centred nature of the Belgian pension system. More specifically, we expect migrant women, and particularly third-country migrant women (i.e. women of Turkish and Maghreb origin), to be less likely than native women to build up pension rights through full-time employment following 
parenthood and more likely (a) to build up pension rights through part-time employment, (b) to build up pension rights based on assimilated periods, or (c) to have no individual pension rights and rely on potential derived pension rights (Hypothesis 1). As first-generation migrant women are less strongly attached to the labour market, we further expect that these women will be more likely than second- and later-generation migrant women to build up assimilated or derived pension rights following parenthood (Hypothesis 2). Finally, we expect that differences between origin groups and migrant generations regarding the build-up of pension rights following family formation can be partially explained by pre-existing differences in the build-up of pension rights before family formation. Particularly, migrant women are less likely to be employed than women of Belgian origin before having a child and therefore more likely to already build up pension rights based on assimilated periods or build up no individual pension rights other than potential derived pension rights (Hypothesis 3 ).

\section{Data and methods}

\section{Data}

The study uses longitudinal micro-data from the Belgian Crossroads Bank for Social Security available in the Data Warehouse Labour Market and Social Protection that combines detailed information on labour market positions available in the Social Security Registers with data on household composition drawn from the National Register. The analysis is based on a random sample of 100,ooo persons aged 18-66 years on 1 January 2011 which was disproportionally stratified by origin and migrant generation. Four groups are distinguished: (a) persons of Belgian origin $(\mathrm{N}=\mathbf{2 5}, \mathrm{ooo})$, (b) first-generation migrants $(\mathrm{N}=25, \mathrm{Ooo})$, (c) second-generation migrants $(\mathrm{N}=25, \mathrm{OOO})$, and (d) later-generation migrants $(\mathrm{N}=25, \mathrm{ooo})$. Given the sample size, the Social Security Registers allow migrant groups to be studied in much greater detail than is typically possible with survey data. An additional advantage of register data is that information on labour market positions and household positions is not affected by non-response. Drawbacks of the Social Security Registers are, however, that data reflect the de jure situation (which may deviate from the factual living arrangement or employment situation) and that data are only available for legal residents (illegal residents are not included in the National Register). Similarly, employees working for supranational organisations (e.g. EU) are not included in the Crossroads Bank for Social Security.

The sample provides annual longitudinal data on various demographic and labour market characteristics for both sampled individuals and their 
household members covering the period 1998-2010. For household members, the information is limited to the years in which they resided in the household of sampled individuals. Demographic variables include age, sex, civil status, current nationality, nationality at birth, nationality and country of birth of (grand)parents, relationship to other household members and region of residence. Labour market characteristics include the number of jobs held, employment status (full-time versus part-time), whether being in an assimilated period (unemployment, parental or care leave), contract type (employee, self-employed or civil servant) and earnings. This information allows the type of pension rights that are built up in a given year by individuals in the active population to be determined, as well as the amount of pension rights that were built up.

Given the focus on the impact of parenthood on the type of pension rights that are built up, we restrict the sample to women who had their first birth between 2000 and 2010. To control for pre-birth employment characteristics, sampled women enter the observation window two years before the birth of their first child and are observed until outmigration or censoring at the end of the observation period in 2010. Women who had their first birth in 1998 or 1999 were excluded from the analyses as information on the build-up of pension rights is not available prior to 1998. Starting the observation two years prior to the birth of the first child allows the determination of whether differential build-up of pension rights by migrant women compared to natives after parenthood can be explained by pre-existing differences in the build-up of pension rights. We control for the situation two years prior to the first birth as previous research has shown that women are unlikely to change employment status around this time in anticipation of their pregnancy. The sample is restricted to Belgium's largest origin groups, distinguishing women of (a) Belgian, (b) Southern European, (c) Western European, (d) Maghreb, (e) Turkish, and (f) Central or Eastern European origin. For migrant women, we additionally distinguish between first-generation versus second- or later-generation migrants as the National Register provides information on current nationality and nationality at birth of both sampled women and their (grand) parents. Women who were not born in Belgium and who did not hold Belgian nationality at the time of birth are considered first-generation migrants. Women who were born in Belgium or who hold Belgian nationality, and who have at least one (grand) parent who held Belgian nationality at the time of birth are regarded as second- or later-generation migrants. The research sample contains 6,267 women: $1,75^{8}$ women of Belgian origin and 4,5 og women of non-Belgian origin. 


\section{Methods}

The analysis consists of two parts. First, the descriptive analyses show the distribution of the type of pension rights that were built up two years before the birth of the first child as well as the distribution of pension rights that are built up in the years following the first birth. The analyses compare the pension rights of native women to those of migrant women, further distinguishing by origin group and migrant generation. Second, we fit two multinomial logit models. Taking native women as a reference group, the first model estimates the effect of origin group and migrant generation on the type of pension rights, only controlling for socio-demographic characteristics of women and their households. The second model estimates the effect of origin group and migrant generation additionally controlling for the type of pension rights that were built up in the two years preceding parenthood. Because observations are nested within persons, the multinomial logit models include an individual-level random disturbance to control for unobserved time-constant characteristics of women that influence the buildup of pension rights before and after entry into parenthood.

The dependent variable is the type of pension rights that women build up in each year following the birth of their first child, distinguishing four types of pension build-up: (a) women who build up full-time pension rights through employment and building up a pension during at least 75 per cent of a year, with at least $5^{\circ}$ per cent of this pension being built up through work (as opposed to assimilated periods); (b) women who build up part-time pension rights through employment and who also realise $5^{\circ}$ per cent or more of their pension rights through work, but they build up pension rights during less than 75 per cent of a year (by either working part-time or by working full-time during a limited period); (c) women who build up full-time pension rights based on assimilated periods-i.e. spells of unemployment or maternity/parental leave - and who realise the majority of their pension rights through assimilation; and (d) women who do not build up any individual pension rights through work or assimilation, but who may receive a derived pension after retirement (because of a working former spouse).

The independent variables are age, divided into five age groups (20-24, $25^{-29}, 33^{-}-34,35^{-39}$ and a larger age interval of women aged $4^{\mathrm{O}-} 5^{\mathrm{O}}$ years as only a limited number of women had a first child at these ages during the observation period), partnership status (a dummy variable indicating whether a partner is present in the household) and parity (distinguishing childless women, women with one child, women with two children and women with three or more children). To control for age differentials in the timing of parenthood, we control for age of women at the birth of their first child 
(centred at 20 years, quadratic effect). We further control for region of residence (distinguishing Belgium's main administrative units Flanders, Wallonia and Brussels) to control for regional variation in labour market opportunities. As mentioned before, we distinguish six origin groups where an additional distinction is made between first versus second or later generation for migrant women. Pre-birth pension rights are operationalised in the same way as the dependent variable and reflect the type of pension rights that women built up two years prior to the birth of their first child. As the build-up of pension rights before family formation is largely determined by labour force participation and employment status, the analyses implicitly control for differences in opportunity structures that women of different origin groups encounter in the labour market. This also partially compensates for the fact that the analyses do not control for educational attainment because this information is not available in the Data Warehouse Labour Market and Social Protection. However, since controlling for pre-birth pension rights partially captures variation in employment status for different origin groups, it can be argued that this also partially captures variation in educational attainment because the latter is an important determinant of activity status.

\section{Results}

\section{Descriptive results}

Figures 1 and 2 plot the distribution of women by type of pension build-up in the two years preceding the birth of the first child (Ch-2 and $\mathrm{Ch}-1$ ), in the year when the first child is born $(\mathrm{Ch})$ and in the ten years following the birth of the first child $(\mathrm{Ch}+1$ to $\mathrm{Ch}+10)$. Figure 1 compares the patterns of first-generation women in different origin groups with the pattern found for native Belgian women, whereas Figure 2 does the same for second- and later-generation women. Marked differences in type of pension build-up by origin group and migrant generation already emerge two years prior to the birth of the first child, largely reflecting variation in labour market positions. Among native Belgian women, the dominant pattern is to build up pension rights through full-time employment (8o per cent of the women), with only 10 per cent of the women building up pension rights through part-time employment. The share of native women who build up pension rights based on assimilated periods amounts to approximately 7 per cent, roughly corresponding to the unemployment rate of childless women of Belgian origin (Kil et al. 2015). The group of native women that does not build up individual pension rights and who may potentially receive derived pension rights from their former husband represents less 

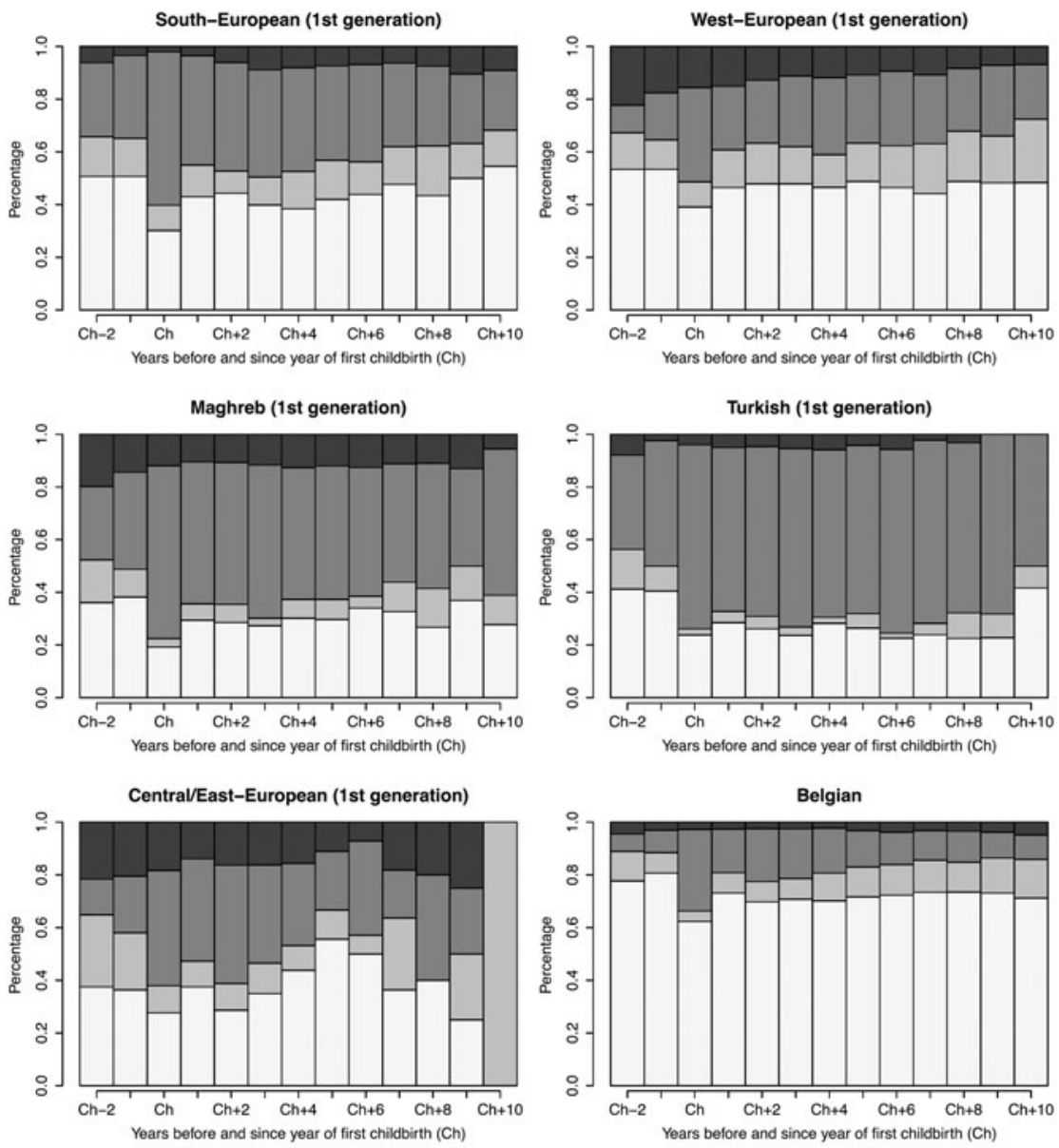

Full-time pension rights through work

- Part-time pension rights through work

- Assimilated full-time pension rights

- No pension rights or potential derived pension

Figure 1. Distribution of pension rights before and after first childbirth by nationality of origin, women who gave birth between 2000 and 2010 : first-generation migrants.

than 3 per cent. Among migrant women, the group that builds up pension rights through full-time employment is substantially smaller than among natives, with considerable heterogeneity emerging in terms of origin group and migrant generation. The share of women of European origin who build up full-time or part-time pension rights through employment ranges between 65 and 80 per cent, whereas this figure ranges between $5^{\mathrm{O}}$ and 60 per cent among women of Turkish and Maghreb origin. Among the latter groups, the share of women who build up full-time 

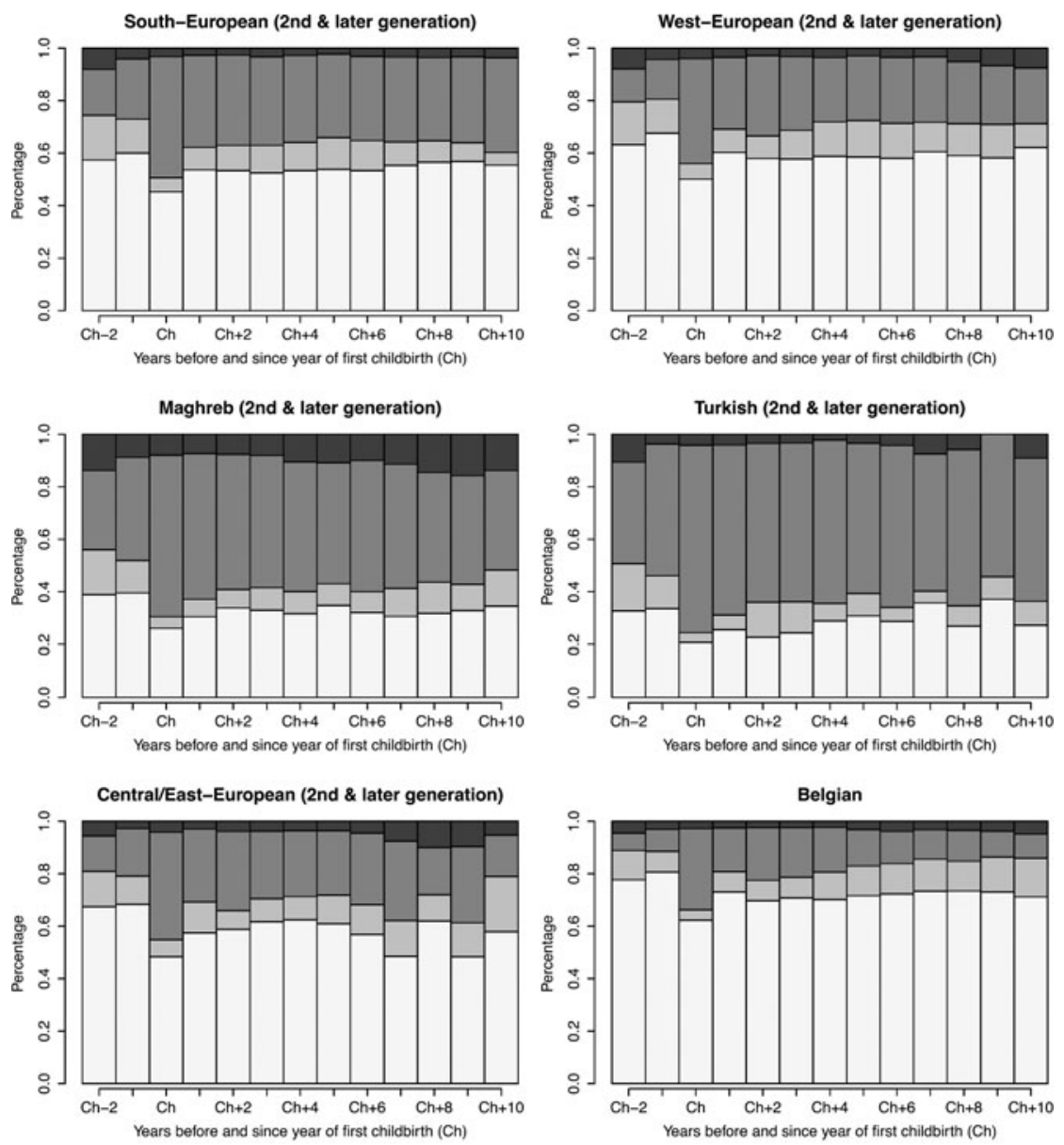

Full-time pension rights through work

Part-time pension rights through work

- Assimilated full-time pension rights

- No pension rights or potential derived pension

Figure 2. Distribution of pension rights before and after first childbirth by nationality of origin, women who gave birth between 2000 and 2010 : second- and later-generation migrants.

pension rights based on assimilated periods is much higher, reflecting the substantially higher unemployment rate in these groups before the start of family formation. Except for women of Turkish origin, second- and later-generation migrants generally do better than first-generation migrants, in the sense that they are more likely to build up pension rights through full-time employment. But even among second- and later-generation migrants, clear differences with native women remain, particularly for women of Turkish and Maghreb origin. 
In the year when the first child is born, there is a marked decrease in the share of women who build up pension rights through full-time employment and an increase in the share of women who build up pension rights based on assimilated periods. Although this partially reflects the fact that many women temporarily leave the labour market following motherhood to take up maternity and/or parental leave, longitudinal analysis of women's labour market trajectories around parenthood has shown that parental leave uptake is more common among native than migrant women, whereas unemployment levels increase among migrant women as they frequently fail to meet the eligibility criteria for parental leave due to prebirth employment positions being generally less stable and the challenge of reconciling irregular employment with care responsibilities (Kil et al. 2015 ; Rendall et al. 2010 ; Wall and Jose 2004).

In the years following the birth of the first child, the share of women who build up pension rights through full-time employment increases again, reflecting women's gradual return to work as their children grow older. The descriptive results suggest a permanent effect of family formation, however, as the share of women who build up pension rights through fulltime employment does not recover to the levels recorded before entry into parenthood, although this may also reflect women progressing to second and higher-order births, which would negatively affect their labour force participation. The decreasing proportion of women building up pension rights through full-time employment goes hand-in-hand with a small increase in the share of women building up pension rights through part-time employment (predominantly among native women), an increasing share of women building up pension rights through assimilated periods (more articulated among migrant women), and an increasing share of women not building up any individual pension rights and therefore solely relying on potential derived pension rights (more prevalent in some origin groups).

In sum, the descriptive results suggest that parenthood has a marked short-term impact on the type of pension build-up of both migrant women and natives, while the build-up of pension rights through full-time or part-time employment is subject to more articulated recovery among native women in the years following the first birth. In the long run, migrant women remain more likely to rely on pension build up through assimilated periods, and more likely to stop building up individual penson rights altogether. However, as differential build-up of pension rights between migrant women and natives after parenthood may be related to differential patterns of family formation-e.g. differential progression to second and higher-order births further affecting maternal employment and pre-birth employment characteristics, a multivariate approach controlling for these factors is required. 


\section{Multivariate results}

Tables 1 and 2 report the odds ratios of (a) building up pension rights through part-time employment, (b) building up pension rights through assimilated periods, and (c) relying on potential derived pension rights (and thus not building up individual pension rights) against the odds of building up pension rights through full-time employment. Whereas the results in Table 1 only compare socio-demographic characteristics, the results in Table 2 additionally control for the type of pension rights that women built up two years before having their first child.

\section{Differentials only controlling for socio-demographic characteristics}

Following parenthood, migrant women are significantly more likely than natives to build up pension rights through part-time employment and assimilated periods, or to fall back on potential derived pension rights from a former spouse (Table 1). The size of the differential with natives varies depending on the type of pension rights. The smallest odds ratios are found for the build-up of pension rights through part-time employment (up to 2.5 times more likely than natives), whereas larger odds ratios are found for building up pension rights through assimilated periods (up to 7.2 times more likely than natives) and potentially relying on derived pension rights (up to 8.8 times more likely than natives).

The size of the differential with natives varies between origin groups and migrant generations. For migrant women of European origin, the differences with native Belgian women are smaller for second- and later-generation migrants than for first-generation migrants. However, even for second- and later-generation women the odds of building up pension rights through part-time employment or assimilated periods, or potentially relying on derived pension rights are 24.9-68.o per cent higher than among Belgian women. Women of Maghreb and Turkish origin are more likely than women of European origin to build up pension rights through assimilated periods. Second- and later-generation Maghreb women are more likely than first-generation women to build up pension rights through fulltime employment, although difference is smaller than among women of European origin. Among women of Turkish origin, second- and later-generation migrants are only slightly less likely than first-generation migrants to build up pension rights based on assimilated periods and even more likely to build up pension rights through part-time employment or to rely on potential derived pension rights.

Entry into parenthood has a pronounced effect on the build-up of pension rights, significantly raising the odds of building pension rights 
T A B L E 1 . Multinomial regression model of pension rights, without controlling for pre-birth pension rights ${ }^{I}$

\begin{tabular}{|c|c|c|c|c|c|c|}
\hline & \multicolumn{2}{|c|}{$\begin{array}{l}\text { Part-time pension } \\
\text { rights through work }\end{array}$} & \multicolumn{2}{|c|}{$\begin{array}{c}\text { Full-time } \\
\text { assimilated } \\
\text { pension rights }\end{array}$} & \multicolumn{2}{|c|}{$\begin{array}{l}\text { No or potential } \\
\text { full-time derived } \\
\text { pension rights }\end{array}$} \\
\hline & $\begin{array}{l}\operatorname{Exp} \\
(B)\end{array}$ & Significance & $\begin{array}{l}\operatorname{Exp} \\
(B)\end{array}$ & Significance & $\begin{array}{l}\operatorname{Exp} \\
(B)\end{array}$ & Significance \\
\hline \multicolumn{7}{|l|}{ Age group (Ref. 20-24) } \\
\hline $25^{-29}$ & $0.65^{2}$ & $* * *$ & $0.45^{8}$ & $* * *$ & 0.474 & $* * *$ \\
\hline $3^{0}-34$ & 0.774 & $* *$ & 0.267 & $* * *$ & 0.471 & $* * *$ \\
\hline $35^{-39}$ & 1.148 & & 0.167 & $* * *$ & $0.5^{6} 3$ & $* * *$ \\
\hline $4^{\mathrm{O}-5^{\mathrm{O}}}$ & 1.594 & $* *$ & 0.115 & $* * *$ & 0.691 & \\
\hline \multicolumn{7}{|l|}{$\begin{array}{l}\text { Nationality of origin } \\
\text { (Ref. Belgian) }\end{array}$} \\
\hline $\begin{array}{l}\text { Southern European } \\
\quad(1 \text { Gen.) }\end{array}$ & 2.422 & $* * *$ & $3 \cdot 353$ & $* * *$ & 1.788 & \\
\hline $\begin{array}{l}\text { Southern European } \\
\quad(2+\text { Gen. })\end{array}$ & 1.274 & $* *$ & 1.645 & $* * *$ & 1.009 & \\
\hline $\begin{array}{l}\text { Western European } \\
\quad \text { ( } 1 \text { Gen.) }\end{array}$ & $2.53^{6}$ & $* * *$ & 2.314 & $* * *$ & 8.593 & $* * *$ \\
\hline $\begin{array}{l}\text { Western European } \\
\quad(2+\text { Gen. })\end{array}$ & $1.3^{18}$ & $* *$ & $1.45^{6}$ & $* * *$ & 1.274 & \\
\hline $\begin{array}{l}\text { Central or Eastern } \\
\text { European ( } 1 \text { Gen.) }\end{array}$ & 2.579 & $* * *$ & $2.75^{2}$ & $* * *$ & $5 \cdot 296$ & $* * *$ \\
\hline $\begin{array}{l}\text { Central or Eastern } \\
\text { European ( } 2 \text { Gen.) }\end{array}$ & 1.271 & & 1.626 & $* * *$ & 1.155 & \\
\hline Maghreb (1 Gen.) & 2.437 & $* * *$ & 6.832 & $* * *$ & 8.855 & $* * *$ \\
\hline Maghreb (2 Gen.) & 1.861 & $* * *$ & 5.292 & $* * *$ & $4 \cdot 449$ & $* * *$ \\
\hline Turkey (1 Gen.) & 1.279 & & 7.223 & $* * *$ & 2.041 & \\
\hline Turkey ( 2 Gen.) & 2.033 & $* * *$ & 6.539 & $* * *$ & 2.532 & $* *$ \\
\hline Has a partner & 0.977 & & 0.667 & $* * *$ & o.8og & $* *$ \\
\hline \multicolumn{7}{|l|}{ Parity (Ref. o children) } \\
\hline 1 child & 0.734 & $* * *$ & 3.299 & $* * *$ & 0.908 & \\
\hline 2 children & 0.783 & $* * *$ & 4.771 & $* * *$ & 1.137 & \\
\hline $3+$ children & 0.916 & & $7 \cdot 722$ & $* * *$ & 2.357 & $* * *$ \\
\hline Age at first birth, linear ${ }^{2}$ & o.793 & $* * *$ & 0.796 & $* * *$ & o.655 & $* * *$ \\
\hline $\begin{array}{l}\text { Age at first birth, } \\
\text { quadratic }^{2}\end{array}$ & 1.006 & $* * *$ & 1.013 & $* * *$ & 1.021 & $* * *$ \\
\hline \multicolumn{7}{|l|}{$\begin{array}{l}\text { Region of residence } \\
\text { (Ref. Flanders) }\end{array}$} \\
\hline Wallonia & 1.309 & $* * *$ & 2.081 & $* * *$ & 1.835 & $* * *$ \\
\hline Brussels & 0.847 & $*$ & 1.165 & $*$ & $1.25^{\mathrm{O}}$ & \\
\hline
\end{tabular}

Notes: 1. Reference group (Ref.): full-time pension rights through work. 2. Centred at 20 years. Source. National Register and the Data Warehouse Labour Market and Social Protection from the Crossroads Bank for Social Security.

Significance levels: $* p<0.05$, ** $p<0.01, * * * p<0.001$. 
T А В L E 2. Multinomial regression model of pension rights, controlling for pre-birth pension rights ${ }^{I}$

No or potential

Part-time pension Full-time assimilated full-time derived rights through work pension rights pension rights

\begin{tabular}{|c|c|c|c|c|}
\hline $\begin{array}{l}\operatorname{Exp} \\
(B)\end{array}$ & Significance & $\begin{array}{l}\operatorname{Exp} \\
(B)\end{array}$ & Significance & Significance \\
\hline
\end{tabular}

\begin{tabular}{|c|c|c|c|c|c|c|}
\hline \multicolumn{7}{|l|}{ Age group (Ref. 20-24) } \\
\hline $25^{-29}$ & 0.557 & $* * *$ & 0.378 & $* * *$ & 0.372 & $* * *$ \\
\hline $3^{0-}-34$ & 0.621 & $* * *$ & 0.189 & $* * *$ & 0.308 & $* * *$ \\
\hline $35^{-39}$ & 0.926 & & 0.107 & $* * *$ & 0.345 & $* * *$ \\
\hline $4^{\mathrm{O}-} 5^{\mathrm{O}}$ & 1.304 & & 0.064 & $* * *$ & 0.457 & $* * *$ \\
\hline \multicolumn{7}{|l|}{$\begin{array}{l}\text { Nationality of origin } \\
\text { (Ref. Belgian) }\end{array}$} \\
\hline Southern European (1 Gen.) & 1.530 & $*$ & 1.993 & $* * *$ & 1.449 & \\
\hline Southern European (2+ Gen.) & 1.020 & & 1.361 & $* * *$ & 0.715 & \\
\hline Western European (1 Gen.) & 1.862 & $* * *$ & 1.723 & $* * *$ & 2.172 & * \\
\hline Western European (2+ Gen.) & 1.183 & & 1.271 & $* * *$ & 1.143 & \\
\hline $\begin{array}{l}\text { Central or Eastern } \\
\text { European ( } 1 \text { Gen.) }\end{array}$ & 1.853 & $*$ & 2.190 & $* * *$ & 1.544 & \\
\hline $\begin{array}{l}\text { Central or Eastern } \\
\text { European }(2+\text { Gen. })\end{array}$ & 1.157 & & 1.469 & $* *$ & 1.104 & \\
\hline Maghreb (1 Gen.) & 1.367 & $*$ & $3 \cdot 478$ & $* * *$ & 2.421 & $* *$ \\
\hline Maghreb (2+ Gen.) & 1.311 & * & 2.996 & $* * *$ & 2.478 & $* *$ \\
\hline Turkey (1 Gen.) & 0.845 & & 3.884 & $* * *$ & 0.994 & \\
\hline Turkey (2+ Gen.) & $1.49^{1}$ & $*$ & $3 \cdot 322$ & $* * *$ & 1.579 & \\
\hline Has a partner & 0.933 & & $0.65^{\circ}$ & $* * *$ & 0.775 & $* *$ \\
\hline \multicolumn{7}{|l|}{ Parity (Ref. o children) } \\
\hline 1 child & 0.661 & $* * *$ & 3.862 & $* * *$ & 0.760 & $* * *$ \\
\hline 2 children & 0.763 & $* * *$ & 6.097 & $* * *$ & 1.042 & \\
\hline $3+$ children & 0.967 & & $10.94^{1}$ & $* * *$ & 2.939 & $* * *$ \\
\hline Age at at first birth, linear ${ }^{2}$ & 1.065 & $*$ & $0.95^{6}$ & $*$ & 1.106 & \\
\hline Age at at first birth, quadratic ${ }^{2}$ & 0.993 & $* * *$ & 1.006 & $* * *$ & $0.99^{8}$ & \\
\hline \multicolumn{7}{|l|}{$\begin{array}{l}\text { Region of residence } \\
\text { (Ref. Flanders) }\end{array}$} \\
\hline Wallonia & 1.008 & & 1.428 & $* * *$ & 1.176 & \\
\hline Brussels & 0.764 & $* *$ & 1.054 & & $1 \cdot 360$ & \\
\hline \multicolumn{7}{|l|}{$\begin{array}{l}\text { Pension rights before childbirth } \\
\text { (Ref. Full-time pension rights } \\
\text { through work) }\end{array}$} \\
\hline No/potential & 7.812 & $* * *$ & 4.665 & $* * *$ & 138.359 & $* * *$ \\
\hline Assimilated & 7.211 & $* * *$ & 21.324 & $* * *$ & $23 \cdot 5^{18}$ & $* * *$ \\
\hline Part-time through work & 13.021 & $* * *$ & 2.643 & $* * *$ & 9.240 & $* * *$ \\
\hline
\end{tabular}

Notes: 1. Reference group (Ref.): full-time pension rights through work. 2. Centred at 20 years. Source: National Register and Data Warehouse Labour Market and Social Protection from the Crossroads Bank for Social Security.

Significance levels: $* p<0.05, * * p<0.01, * * * p<0.001$ 
through assimilated periods. Compared to the situation before parenthood, the odds of building up pension rights through assimilated periods are 3.3 times higher than the odds of building up pension rights through full-time employment. The odds ratios increase further for women having a second and particularly a third child (odds ratios of 4.8 and 7.7 , respectively). Having three children or more also raises the probability of relying on potential derived pension rights, reflecting lower labour force participation in this group. When women have children, the odds of building up pension rights through part-time rather than full-time employment are generally lower than before the entry into parenthood, controlling for covariates and alternative types of pension build-up.

The timing of entry into parenthood is also strongly associated with the build-up of pension rights. Postponement of parenthood, particularly at younger ages, is negatively associated with building up pension rights through part-time employment or assimilated periods, or relying on potential derived pension rights, indicating that women who postpone parenthood until being firmly established in the labour market are also more likely to continue their build-up of pension rights through full-time employment after entry into parenthood. The size of the effect is roughly similar for the different types of pension build-up. Partnership status also affects the type of pension build-up. The odds of building up pension rights based on assimilated periods or to rely on potential derived pension rights rather than building up pension rights through full-time employment are, respectively, 23 and 19 per cent lower when a partner is present in the household, indicating that single mothers are more likely to be unemployed or inactive than mothers in a relationship (Van Lancker, Ghysels and Cantillon 2012).

Finally, we tested whether the effect of family formation on the build-up of pension rights differed by origin group and by migration generation (results not shown). We found that migrant women are more likely than Belgian women to rely on potential derived pension rights following parenthood. On the other hand, we also found that the positive effect of family formation on building up pension rights through assimilated periods is smaller among women of non-Belgian origin. Recent research for Belgium has shown, however, that women of Belgian origin are more likely to take up parental leave than women of non-Belgian origin whereas migrant women are more likely to become unemployed, which may partly explain the finding on assimilated pension rights (Kil et al. 2015). It should be noted, however, that the interaction terms (both for assimilated and derived pension rights) were not always significant. 


\section{Differentials controlling for type of pension rights built up before parenthood}

Controlling for the type of pension rights that women built up before entering parenthood has the effect of reducing the differential build-up of pension rights between migrant women and natives after parenthood (Table 2). The differentials between migrant women and natives have particularly declined for the build-up of pension rights based on assimilated periods as well as derived pension rights. This suggests that the lower likelihood of migrant women building up pension rights through full-time employment after entry into parenthood to an important extent reflects the fact that they were already less likely to build up pension rights through full-time employment before having their first child. Similar to the previous findings, women of Maghreb and Turkish origin are more likely than other origin groups to build up pension rights through assimilated periods or to rely on potential derived pension rights. As expected, the reduction of the odds ratios is more pronounced for first-generation migrants than for second- and later-generation migrants, highlighting that first-generation migrants were already more likely than second- and latergeneration migrants to build up pension rights through channels other than labour force participation before parenthood. Although differentials in terms of migrant generation have equally become smaller, firstgeneration migrants (except Turkish women) are still more likely than second- and later-generation migrants to build up pension rights through part-time employment and assimilated periods, or to rely on derived pension rights. The same picture emerges when we compare the pension rights of second- and later-generation migrants to the pension rights of native Belgian women.

The effect of entry into parenthood has remained largely similar to the results of the first model. Parenthood mainly increases the odds of building up pension rights through assimilated periods, with the effect being less pronounced among migrant women. Controlling for the type of pension rights women built up before parenthood has altered the effect of the timing of parenthood. Both the linear and quadratic terms of age at first birth are now close to unity, suggesting that the timing of parenthood has little impact on the likelihood of building up particular pension rights once pre-birth differentials in pension build-up are taken into account. The effect of partnership status has remained quite similar to the results of the first model. The presence of a partner decreases the odds of building up pension rights based on assimilated and derived periods by about 45 and 22 per cent, respectively.

As expected, the type of pension rights women built up before parenthood is strongly associated with the type of pension rights built up following 
parenthood. Women who built up pension rights through part-time employment in the years before parenthood are also more likely to build up pension rights through part-time employment following parenthood. Similarly, women who built up pension rights through assimilated periods or had no individual pension rights other than potential derived pension rights prior to parenthood are also more likely to continue doing so after entry into parenthood.

\section{Discussion and conclusions}

This paper aimed to analyse whether entry into parenthood and subsequent family formation differentially affects pension protection of migrant women compared to natives, considering the low levels of maternal employment witnessed in migrant populations and the well-documented penalties in pension protection resulting from the gendered impact of parenthood on work-care trajectories. For native women, the results show that family formation affects the build-up of pension rights by increasing the likelihood that women build up pension rights through assimilated periods shortly after the first birth, as they temporarily leave the labour market and take up maternity and parental leave. In the years following the first birth, the share of women who return to the labour market gradually increases, which translates into a rising share of women who build up pension rights through full-time employment. The results indicate, however, that family formation leaves a permanent footprint on women's build-up of pension rights, as the share of women who build up full-time pension rights through employment does not recover to the levels recorded before parenthood. The build-up of pension rights through assimilated periods and reliance on potential derived pension rights is even higher among women who have a second or higher-order birth, as these women have a higher probability of temporarily (or permanently) leaving the labour market to take up care responsibilities.

For migrant women, we find that the likelihood of building-up pension rights through assimilated periods or relying on potential derived pension rights (i.e. not building up individual pension rights) is higher in all origin groups than is the case for natives, similar to results documented earlier for the United Kingdom and Canada. Native women predominantly build up full-time pension rights through employment shortly before and after giving birth, whereas this is less articulated among migrant women. Furthermore, the analyses show considerable heterogeneity between origin groups. Women of European origin are more likely than women of Turkish and Maghreb origin to build up pension rights through full-time employment 
(Hypothesis 1), reflecting the more precarious position of women of Turkish and Maghreb origin in the labour market. In the latter origin groups, about one-third of the women are not employed before entry into parenthood and this percentage declines even further after family formation. For women of Turkish and Maghreb origin, assimilated and potential derived pension rights are therefore an important source of pension protection.

Not only do pension rights differ between origin groups, the analyses show that there are also important differences within origin groups. Second- and later-generation migrants are more likely than first-generation migrants to build up pension rights through full-time employment, which reflects their better position in the labour market. But even though second- and later-generation migrants are less likely than first-generation migrants to build up assimilated or potential derived pension rights, they are still less likely to build up pension rights through full-time employment than native women, particularly among women of Maghreb and Turkish origin (Hypothesis 2). Finally, the analyses reveal that differentials in the build-up of pension rights are already pronounced before the start of family formation and that these differentials explain to a large extent the differentials in pension build-up following family formation. Particularly, the over-representation of first-generation migrant women in assimilated and potential derived pension rights after parenthood stems from the fact that these women were already more likely to build up pension rights through these pathways before entry into parenthood (Hypothesis 3 ).

The findings of this paper provide some insights into the challenges that European pension systems currently face and also raise questions on policies propagating individualisation of pension rights based on labour market participation, privatisation of pension systems and decreased importance of derived pensions. The results of our study show that the more adverse position of migrant populations in the labour market does not only have consequences on their immediate income situation but also has clear implications for the income protection these groups can expect upon retirement. Research on inequalities in pension protection should further address differential pension protection between migrant women and natives, and how these differences are associated with household transitions that have clear implications for women's work-care trajectories and hence pension protection. Given the importance of assimilated periods and potential derived pension rights in the pension build-up of migrant women, policies that reinforce the individualisation of pension rights based on labour market participation, increase privatisation and/or decrease the importance of potential derived pension rights are likely to erode pension protection of groups having limited access to the labour market, such as migrant women (Frericks, Maier and De Graaf 2007; 
Price 2007; Vlachantoni 2010). Pension reforms along these lines therefore require co-ordination with employment policies that reduce barriers for migrant women for gaining access to the labour market, as well as family policies that reduce existing ethnic differentials in the uptake of parental leave and formal child care to support the reconciliation of maternal employment with care responsibilities (Frericks, Maier and De Graaf 2007; Rendall et al. 2010; Vlachantoni 2010; Wall and Jose 2004). The finding that differences between origin groups in the build-up of pension rights after parenthood can be explained to a considerable extent in terms of differentials in pension build-up before parenthood suggests that strengthening labour market positions of migrant women prior to parenthood would have a substantial impact on pension protection of migrant women, as women who are well established in the labour market before giving birth are less likely to exit the labour market after parenthood (Kil et al. 2015). As the pension system in Belgium (as in other European countries) has come under increasing pressure as a result of rapid population ageing and low economic growth prospects, improving the labour market position of migrant populations, including women, is also mandatory from a macro-level perspective to maintain the size of the labour force and counter the trend of declining dependency ratios (Holland and De Valk 2013; OECD 2008, 2010).

To conclude, we draw attention to a number of limitations of this study and point out avenues for further research. Although the results show that the Belgian pension system allows women to build up pension entitlements during spells of unemployment and inactivity, more research is needed to ascertain whether and to what extent the amount of pension that women build up during such assimilated periods is lower compared to women who build up pension rights through spells of employment. The fact that workers of migrant origin are over-represented in unskilled jobs and have lower average income (Corluy and Verbist 2014; Kogan 2007) will likely negatively affect the amount of pension they will ultimately build up. Similarly, the income protection of women relying on derived pension rights deserves closer scrutiny, particularly in the case of marital dissolution. Finally, the current study has only considered the build-up of pension rights in the first pillar, whereas research suggest that sizeable ethnic differentials are also likely to exist in the second and third pension pillars (Ginn and Arber 2001; Hersch and Whitemeans 1993; Vlachantoni et al. 2015).

\section{Acknowledgements}

We thank the Deputy Editor and an anonymous reviewer for their useful suggestions and comments. We thank Lise Cordeel, Nina Donvil and Nele Havermans for their 
1276 Karel Neels et al.

assistance in handling the register data and their comments on earlier versions of this paper.

\section{NOTE}

1 This section is based on Peeters (2016), unless mentioned otherwise.

\section{References}

Becker, G. 1991. A Treasise on the Family. Enlarged edition, Harvard University Press, Cambridge, Massachusetts.

Bettio, F., Tinios, P. and Betti, G. 2013. The Gender Gap in Pensions in the EU. Directorate-General for Justice, European Commission, Brussels.

Bonnet, C., Buffeteau, S. and Godefroy, P. 2006. Effects of pension reforms on gender inequality in France. Population, 61, 1/2, 45-75.

Bonnet, C., Meurs, D. and Rapoport, B. 2015. Gender-based pension inequality in the public and private sectors: a distribution analysis. Revue De l'Ires, 87, 4, 35-61.

Corijn, M. and Lodewijckx, E. 2009. De start van de gezinsvorming bij de Turkse en Marokkaanse tweede generatie in het Vlaams gewest. Een analyse op basis van Rijksregistergegevens [The Start of Family Formation Among the Turkish and Moroccan Second Generation in the Flemish Region. An Analysis Based on the National Register]. Studiedienst van de Vlaamse Regering, Brussels.

Corluy, V. and Verbist, G. 2014. Can education bridge the gap? Education and the employment position of immigrants in Belgium. Improve Working Paper Series, Volume 14-02, Herman Deleeck Centre for Social Policy, University of Antwerp, Antwerp, Belgium.

Davies, H., Joshi, H. and Peronaci, R. 20oo. Foregone income and motherhood: what do recent British data tell us? Population Studies, 54, 3, 293-305.

Eggerickx, T., Kesteloot, C. and Poulain, M. 1999. Algemene Volks- en Woningtelling op I maart I99I. De allochtone bevolking in België [The Census of March Ist I99I. The Migrant Population in Belgium]. Ministerie van Economische Zaken, Nationaal Instituut voor de Statistiek, Brussels.

Even, W. E. and Macpherson, D. A. 1994. Gender differences in pensions. Journal of Human Resources, 29, 2, 555-87.

Federaal Planbureau 2013. Bevolkingsvooruitzichten 20I 2-206o [Population Prospects 20 I 2-2060]. Federaal Planbureau en Algemene Directie Statistiek, Brussels.

Frericks, P., Maier, R. and De Graaf, W. 2007. European pension reforms: individualization, privatization and gender pension gaps. Social Politics, 14, 2, 212-37.

Ginn, J. and Arber, S. 1993. Pension penalties - the gendered division of occupational welfare. Work, Employment and Society, 7, 1, 47-70.

Ginn, J. and Arber, S. 2001. Pension prospects of minority ethnic groups: inequalities by gender and ethnicity. British Journal of Sociology, 52, 3, 519-39.

Grady, J. 2015. Gendering pensions: making women visible. Gender, Work and Organization, 22, $5,445^{-} 5^{8 .}$

Heath, A. F., Rothon, C. and Kilpi, E. 2008. The second generation in Western Europe: education, unemployment, and occupational attainment. Annual Review of Sociology, 34, 21 1-35.

Hersch, J. and Whitemeans, S. 1993. Employer-sponsored health and pension benefits and the gender/race wage gap. Social Science Quarterly, 74, 4, 851-66. 
Holland, J. and de Valk, H. 2013. The employment of Turkish second generation women in Europe in comparative perspective. European Commission, Brussels (www.neujobs.eu).

Kil, T., Neels, K., Van den Berg, L. and De Valk, H. 2015. Arbeidsmarkttrajecten van vrouwen met een migratie-achtergrond voor en na de geboorte van een eerste kind. [Labour market trajectories of migrant women before and after the birth of a first child]. Over.werk, 25, 2, 127-34.

Kogan, I. 2007. A study of immigrants' employment careers in West Germany using the sequence analysis technique. Social Science Research, 36, 2, 491-511.

Leitner, S. 2001. Sex and gender discrimination within EU pension systems. Journal of European Social Policy, 11, 2, 99-115.

Lewis, J. 2001. The decline of the male breadwinner model: implications for work and care. Social Politics, 8, 2, 152-69.

Liefbroer, A. C. and Corijn, M. 1999. Who, what, where, and when? Specifying the impact of educational attainment and labour force participation on family formation. European Journal of Population, 15, 1, 45-75.

Lodewijckx, E. 2013. Recente immigranten in Vlaanderen. Wie zijn ze? [Recent immigrants in Flanders. Who are they?]. SVR-Webartikel 2013/1, Studiedienst van de Vlaamse Regering, Brussels.

Marier, P. 2007. Affirming, transforming, or neglecting gender? Conceptualizing gender in the pension reform process. Social Politics, 14, 2, 182-211.

Marier, P. and Skinner, S. 2008. The impact of gender and immigration on pension outcomes in Canada. Canadian Public Policy-Analyse de Politiques, 34, Supplement $1, \mathrm{~S}_{59}-\mathrm{S}_{7} 8$.

Meyer, T. and Bridgen, P. 2008. Class, gender and chance: the social division of welfare and occupational pensions in the United Kingdom. Ageing $\mathcal{E}^{\circ}$ Society, 28, 3, 353-81.

Münz, R., Straubhaar, T., Vadeau, F. and Vadeau, N. 2007. What Are the Migrants' Contributions to Employment and Growth? A European Approach. HWWI Migration Research Group, Hamburg, Germany.

O'Rand, A. M. and Shuey, K. M. 2007. Gender and the devolution of pension risks in the US. Current Sociology, 55, 2, 287-304.

Organisation for Economic Co-operation and Development (OECD) 2008. The labour market integration of immigrants and their children in Belgium. In Jobs for Immigrants. Volume 2: Labour Market Integration in Belgium, France, the Netherlands and Portugal. OECD Publishing, Paris, 43-108.

Organisation for Economic Co-operation and Development (OECD) 2010. International Migration Outlook: SOPEMI 20Io. OECD Publishing, Paris.

Organisation for Economic Co-operation and Development (OECD) 201 1 a. Doing Better for Families. OECD Publishing, Paris.

Organisation for Economic Co-operation and Development (OECD) $2011 b$. International Migration Outlook: SOPEMI 201 I. OECD Publishing, Paris.

Peeters, H. 2016. The devil is in the detail. Delving into Belgian pension adequacy. $\mathrm{PhD}$ dissertation, Centre for Sociological Research, Leuven, Belgium.

Price, D. 2007. Closing the gender gap in retirement income: what difference will recent UK pension reforms make? Journal of Social Policy, 36, 4, 561-83.

Rendall, M. S., Tsang, F., Rubin, J. K., Rabinovich, L. and Janta, B. 2010 . Contrasting trajectories of labor-market integration between migrant women in Western and Southern Europe. European Journal of Population-Revue Europeenne De Demographie, 26, $4,3^{8} 3^{-4} 10$. 
Renga, S., Molnar-Hidassy, D. and Tisheva, G. 2010. Direct and Indirect Gender Discrimination in Old-age Pensions in 33 European Countries. Directorate-General for Justice, European Commission, Brussels.

Rubin, J., Randall, M.S., Rabinovich, L., Tsang, F., Van Oranje Nassau, C. and Janta, B. 2008. Migrant Women in the European Labour Force. RAND Europe, Cambridge.

Samek Lodovici, M., Crepaldi, C., Corsi, M. and Naaf, S. 2011. The Socio-economic Impact of Pension Systems on the Respective Situations of Women and Men and the Effects of Recent Trends in Pension Reforms. Directorate-General for Justice, European Commission, Brussels.

Sigle-Rushton, W. and Waldfogel, J. 2007. Motherhood and women's earnings in Anglo-American, Continental European, and Nordic countries. Feminist Economics, 13, 2, 55-91.

Timmerman, C., Vanderwaeren, E. and Crul, M. 2003. The second generation in Belgium. International Migration Review, 37, 4, $1065^{-90 .}$

Urso, G. and Schuster, A. 2013. Migration, Employment and Labour Market Integration Policies in the European Union. International Organization for Migration, Brussels.

Van Lancker, W., Ghysels, J. and Cantillon, B. 201 2. De impact van kinderbijslagen op het armoederisico van alleenstaande moeders: België in vergelijkend perspectief [The Impact of Child Benefits on the Poverty Risk of Lone Mothers. Belgium from a Comparative Perspective]. Centrum voor Sociaal Beleid Herman Deleeck, Antwerpen, Belgium.

Vause, S. 2013. Migraties en migrantenpopulaties in België. Statistisch en demografisch verslag 2013 [Migration and Migrant Populations in Belgium. Statistical and Demographic Report 2013]. Centre de Recherche en démographie et sociétés (DEMO) and Centrum voor Gelijkheid van Kansen en voor Racismebestrijding, Brussels.

Vlachantoni, A. 2010. Gender and pension individualisation: the case of Greece. South European Society and Politics, 15, 2, 225-45.

Vlachantoni, A., Feng, Z., Evandrou, M. and Falkingham, J. C. 2015. Ethnicity and occupational pension membership in the UK. Social Policy and Administration, 49, 7, 801-23.

Wall, K. and Jose, S.J. 2004. Managing work and care: a difficult challenge for migrant families. Social Policy and Administration, 38, 6, 591-621.

Wood, J., Neels, K. and Kil, T. 2014. The educational gradient of childlessness and cohort parity progression in 14 low fertility countries. Demographic Research, 31 , 46 , $1365-416$.

Accepted 20 December 20I6; first published online 28 February 2017

Address for correspondence:

Karel Neels,

Centre for Longitudinal \& Life Course Studies,

University of Antwerp, Sint Jacobstraat 2,

B-20oo Antwerp, Belgium

E-mail: Karel.Neels@uantwerpen.be 